\title{
INCORPORATION AND IMPLEMENTATION - THE EXECUTION OF THE EEA AGREEMENT BY THE ICELANDIC STATE
}

\author{
MARGRÉT EINARSDÓTTIR*
}

\begin{abstract}
The EE A Agreement is the most extensive international agreement Iceland has entered into, and plays a vital role in the country's economy. The principal objective of the Agreement is to expand Europe's internal market, so that the four freedoms, ie free movement of goods, persons, services and capital, apply not only to the EU Member States, but also to the EEA EFTA States. The execution of the EEA Agreement is a complicated task and entails two steps; Firstly, EU acts (that are EEA-relevant), have to be incorporated into the EEA Agreement. Secondly the EE $A$ acts need to be implemented at national level. This two-step process, has not been working sufficiently well in recent years, resulting in failure by the Icelandic state to fulfil its obligations on the basis of the EEA Agreement. The aim of this paper to to explain why, by defining and analysing all the factors that binder the incorporation of $E U / E E A$ law into the EE $A$ legal order and implementation into Icelandic law. Furthermore the paper aims to provide suggestions on how to improve these processes. This paper argues that there are two underlying principal reasons for this poor performance. Firstly, changes within the EU have added new challenges to the execution of the EEA Agreement. Secondly, a certain lack of willingness among Icelandic politicians to accept the realities of the EEA agreement has led to delays in the proccesses.
\end{abstract}

\section{INTRODUCTION}

On 22 September 2017, British Prime Minister, Theresa May argued that a post-Brexit UK accepting EEA membership would mean accepting rules without influence or votes, which would inflict a 'loss of democratic control' that British voters would not accept. ${ }^{1}$ Is it true that EEA membership entails a loss of democratic control? And if so, has it effected the execution of the EEA Agreement by Iceland? ${ }^{2}$ These are among the principal questions addressed in this paper.

The EEA Agreement is an international agreement between the EEA EFTA States (Iceland, Norway and Lichtenstein) and the European Union and its Member States. The principal objective of the EEA Agreement is to expand Europe's internal market, so that the four freedoms, ie free movement of goods, persons, services and capital, apply not only to

\footnotetext{
*Associate Professor at Reykjavik University, Iceland. LL.M., University of Cambridge 2006. Ad-hoc College Member of the EFTA Surveillance authority. The author would like to thank Ciarán Burke, Davíð Dór Björgvinsson, Hulda Kristín Magnúsdóttir, M. Elvira Méndez-Pinedo, Ólafur Ísberg Hannesson and Páll Hreinsson for their valuable feedback.

1 The Guardian, 22 September 2017.

2 The term 'execution of the EEA Agreement' covers both the process of incorporation of legislative acts of the EU into the EEA Agreement and subsequent implementation of the acts into national law.
} 
the EU Member States, but also to the EEA EFTA States. ${ }^{3}$ The EEA Agreement is without doubt the most extensive international agreement Iceland has entered into and is vital for Iceland's economy. ${ }^{4}$ Via the Agreement, Iceland, a country with a population just shy of 340,000 inhabitants ${ }^{5}$, has access to free movement of goods, ${ }^{6}$ services and capital in an area with a population of over 500 million. ${ }^{7}$ In addition, the Agreement entitles Icelanders to live, work and study anywhere within this area. The EEA Agreement is thus of great importance for Iceland both in economic and cultural terms. ${ }^{8}$ Despite this fact, the Icelandic state has in recent years not complied with its obligations on the basis of the EEA Agreement. ${ }^{9}$ The aim of this paper is to explain the factors that have contributed to delays in the execution of the Agreement and provide suggestions on how to improve it.

The paper is organised in the following manner: Section 2 describes some relevant components of the EEA Agreement; Section 3 focuses on the problems facing the Icelandic Government concerning the incorporation of EU secondary law into the EEA Agreement, while the Norwegian incorporation process is examined by way of comparison; Section 4 discusses the implementation problems of EEA secondary law into Icelandic law. Comprehensive researches conducted by European scholars on the causes of the implementation problems in the EU Member States, provide here an important insight concerning the root causes of implementation problems in Iceland. Finally, in Section 5, proposals are made on how to improve the execution of the EEA Agreement in Iceland.

\section{THE FRAMEWORK OF THE EEA AGREEMENT}

As previously stated, the principal objective of the EEA Agreement is to expand Europe's internal market, so that the four freedoms, ie free movement of goods, persons, services and capital, apply not only to the EU Member States, but also to the EEA EFTA States. In order to achieve this goal, it is necessary that the same rules apply to the EEA EFTA States and

\footnotetext{
${ }^{3}$ See more detailed discussion on the goals of the EEA Agreement in Frank Büchel and Xavier Lewis, 'The EFTA Surveillance Authority', in C. Baudenbacher (eds.), The Handbook of EEA Law (Springer 2016) 117-119 and Halvard Haukeland Fredriksen, 'EEA Main Agreement and Secondary EU Law Incorporated into the Annexes and Protocols', in C. Baudenbacher (eds.), The Handbook of EEA Law (Springer 2016) 96.

${ }^{4}$ Information material on the EEA Agreement from the website of the Ministry of Foreign Affairs in Iceland. <https://www.utanrikisraduneyti.is/verkefni/evropumal/verkefni/nr/4578> accessed 6 June 2018.

${ }^{5}$ Information material on the website: <https://hagstofa.is/utgafur/frettasafn/mannfjoldi/mannfjoldinn-a4-arsfjordungi-2016> accessed 22 January 2018.

${ }^{6}$ Not, however, agricultural goods and marine products in all respects, as provided for in Part II of the EEA Agreement.

${ }^{7}$ Iceland's Accession Negotiations, A report commissioned by the Icelandic Confederation of Labour, the Confederation of Icelandic Employers, the Icelandic Federation of Trade and the Iceland Chamber of Commerce, (Reykjavík 2014) 96: <http://ams.hi.is/wp-content/uploads/2014/03/Uttekt-AMS-umadildarvidraedur-Islands-vid-ESB.pdf $>$. Summary of the report is available in English at $<$ https://ams.hi.is/wp-content/uploads/2014/03/IIA_EU_Iceland_Report_Executive-Summary.pdf $\geq$ accessed 10 January 2018.

8 Reference may be made here to the European Policy of the Icelandic Government, the Ministry for Foreign Affairs (Reykjavík 11 March 2014). See <https://.utanrikisraduneyti.is/media/esb/Evropustefna.pdf> accessed 5 January 2018.

9 See Margrét Einarsdóttir, 'Upptaka afleiddrar löggjafar í EES-samninginn og innleiðing í íslenskan rétt' ['The incorporation of EU secondary law into the EEA Agreement and the implementation into Icelandic national law'], (2005) Tímarit lögfræðinga 545. The main conclusion of the article is that the execution of the EEA Agreement, by the Icelandic state, does not comply with its obligations on the basis of the EEA Agreement.
} 
the EU Member States as regards the internal market. The EEA Agreement, therefore, contains provisions that have the same substance as the basic provisions of the Treaty on the functioning of the European Union (TFEU) regarding the 'four freedoms'.

Accordingly the EEA Agreement entails an obligation to incorporate EU acts that falls within the scope of the Agreement (dubbed as being EEA relevant). The main role of the EEA Joint Committee ${ }^{10}$ is to incorporate these acts, established by the bodies of the EU, into the EEA Agreement. When secondary law has been incorporated into the Agreement, the EEA EFTA states are under obligation to implement regulations and directives into their internal legal order, as provided for in Article 7 of the Agreement.

\subsection{TWO-PILLAR SYSTEM}

The EEA EFTA States have not transferred legislative competences to the joint EEA bodies $^{11}$ and 'are also unable, constitutionally, to accept decisions made by EU institutions directly $^{\text {12 }}$. To adapt to this situation, the EEA EFTA States have their own institutions, on the basis of the EEA Agreement and the Agreement between the EFTA States on the Establishment of a Surveillance Authority and a Court of Justice (SCA). These EEA EFTA bodies match those on the EU side. ${ }^{13}$ The EEA EFTA institutions and the EU institutions form the two pillars, while the joint EEA bodies are situated between them. ${ }^{14}$

The most important joint EEA body, from the perspective of the day-to-day management of the EEA Agreement, is the EEA Joint Committee. In this Committee, representatives from the EFTA pillar (the EFTA Standing Committee) and from the EU pillar (the EU European External Service) meet. As already mentioned the committee's main role is to incorporate EU acts, enacted by the EU legislative bodies, into the EEA Agreement. ${ }^{15}$ As discussed in the next section, once secondary legislation has been incorporated into the Agreement the EEA EFTA states are under obligation to implement it into their national legislation.

\footnotetext{
10 The EEA Joint Committee is responsible for the management of the EEA Agreement and typically meets six to eight times a year. It is a forum in which views are exhanged and decisions are taken by consensus to incorporate EU legislation into the EEA Agreement. The EEA Joint Committee is comprised of representatives from the EFTA Standing Committee (the ambassadors of the EEA EFTA States) and representatives of the European External Action Service. Information material on the EEA Agreement from the website of EFTA < http://www.efta.int/eea/eea-institutions/eea-joint-committee> accessed 2 June 2018. 11 The EEA joint bodies are; the EEA Council, the EEA Joint Committee, the EEA Joint Parliamentary Committee and the EEA Consultative Committee, see the webpage of EFTA: <http://www.efta.int/eea/eeaagreement/eea-basic-features> accessed 2 June 2018.

12 See the webpage of EFTA: <http://www.efta.int/eea/eea-agreement/eea-basic-features> accessed 2 June 2018.

${ }^{13}$ For example the EFTA Court and the EFTA surveillance authority (ESA) are parallels to the Court of Justice of the European Union and to the European Commission. Other EEA EFTA institutions are the EFTA Standing Committe, the Committee of MPs of the EFTA States and the EFTA Consultative Committee. These institutions mirror - in the correct order - the European External Action Service, the European Parliament and the Economic and Social Committee. See the webpage of EFTA:

<http://www.efta.int/eea/eea-agreement/eea-basic-features> accessed 3 June 2018.

${ }^{14}$ Georges Baur, 'Decision-Making Procedure and Implementation of New Law', in C. Baudenbacher (eds.), The Handbook of EU Law, (Springer 2016) 47-48.

15 ibid.
} 
EEA law does not entail a transfer of legislative power. Unlike EU law, EEA law does therefore not have direct applicability or direct effect. In order for an individual or legal entity to rely on rights protected by the EEA Agreement, these rights must be implemented into the domestic laws of the EEA EFTA States, cf. Art. 7 EEA and Protocol 35. ${ }^{16}$

Iceland and Norway, as dualist states, therefore need to implement regulations into their domestic laws. EU Member States however need not do so as regulations issued by the EU's legislative bodies are 'directly applicable', as provided for in Article 288 TFEU. ${ }^{17}$

Both EEA EFTA States and EU Member States are required to implement directives into their national law. However, unlike directives in the EEA EFTA States, directives in the EU are capable of vertical direct effect, (if they are unconditional and sufficiently clear and precise) meaning that directives may be enforced directly by individuals against the State after the time limit for their implementation has expired, even if they have not been implemented, or have been incorrectly implemented, into domestic law. ${ }^{18}$

Via Article 2 of the European Economic Area Act No. 2/1993, the main part of the EEA Agreement acquired legal force in Icelandic domestic law. Individuals and legal entities may therefore rely on rights protected by the provisions of the EEA Agreement. However, the implementation of EEA secondary law into the Icelandic legal system represents an ongoing process, cf. Article 7 of the EEA Agreement.

\section{THE MAIN REASONS UNDERLYING THE INCORPORATION PROBLEMS}

When the EEA Agreement was signed on 2 May 1992, 1,875 EU acts fell within its ambit. ${ }^{19}$ Since that time, about 10,000 acts have been incorporated into the Agreement, of which approximately 6000 remain in force. ${ }^{20}$

Decisions concerning whether EU acts should be a part of the EEA agreement are, as previously stated, made during the meetings of the EEA Joint Committee. Before such proposals are submitted to the EEA Joint Committee, extensive preparations are carried out where the EFTA Secretariat, the sub-committees of the EFTA Standing Committee and

\footnotetext{
16 This was clearly confirmed for the first time in the ruling of the EFTA Court in the Case E-4/01 Karl K. Karlsson v. the Icelandic State, [2002] Report of the EFTA Court 240 (para. 28), which stated that: 'It follows from Article 7 EEA and Protocol 35 to the EEA Agreement that EEA law does not entail a transfer of legislative powers. Therefore, EEA law does not require that individuals and economic operators can rely directly on non-implemented EEA rule before national courts.' The EFTA Court has since reiterated this on numerous occasions, see eg rulings of the EFTA Court in Cases E-11/14 ESA v. the Icelandic State, [2015] Report of the EFTA Court 4; E-14/14 ESA v. the Icelandic State, [2015] Report of the EFTA Court 30; E20/14 ES A v. the Icelandic State, [2015] Report of the EFTA Court 192; and E-1/15 ESA v. the Icelandic State, [2015] Report of the EFTA Court 330. See also M. Elvira Méndez-Pinedo, EC and EEA Law, A Comparative Study of the Effectiveness of European Law, (International Specialized Book Service Incorporated 2009) 163-165 and Sigurður Líndal and Skúli Magnússon, Réttarkerfi Evrópusambandsins og Evrópska efnahagssvađisins [The legal system of the European Union and the European Economic Area] (Hið íslenska bókmenntafélag 2011) 135-136.

17 Méndez-Pinedo (n 16) 62.

18 Méndez-Pinedo (n 16) 63-66 and Steiner \& Woods, EU Law (Oxford University Press 2017) 119-127.

${ }^{19}$ Information obtained from the EFTA Secretariat on 15 December 2015.

${ }^{20}$ See $<$ www.efta.int/eea-lex> accessed 15 June 2018.
} 
working groups play key roles. ${ }^{21}$ In addition, Icelandic 'rules on the parliamentary procedure for matters concerning EEA', apply that provide for the manner in which to prepare for the decision of the EEA Joint Committee in Iceland. This process involves a comprehensive consultation by the Icelandic administration with Alpingi (the Icelandic Parliament).

Once all three EEA EFTA States have adequately prepared for incorporation, the EU acts are submitted to the EEA Joint Committee for incorporation into the EEA Agreement. The incorporation of EU acts into the EEA Agreement shall take place 'as closely as possible to the adoption by the Community of the corresponding new Community legislation with a view to permitting a simultaneous application' of law in the EU Member States and the EEA EFTA States, cf. Article 102. ${ }^{22}$

The contracting parties are aware that it is impossible to attain the goal of Article 102 and eliminate all 'backlog'; (ie accumulated acts that have not been incorporated into the EEA Agreement even though their compliance date in the EU Member States has passed) as there is a certain delay built into the EEA Agreement. Rather, the realistic goal is to keep the extent of this backlog as little as possible. ${ }^{23}$ There is no fixed rule as to an acceptable duration of delay, although a delay of 6 to 9 months may be considered normal and a delay of less than one year can be considered acceptable. If the incorporation is further delayed, this has significant harmful effects on the object of the Agreement, (ie homogenous European Economic Area), as different legislation is then in force in the EU Member States than the EEA EFTA States, for an extended period. ${ }^{24}$

Between 2000 and 2010, the EU and EEA EFTA States appear to have been relatively satisfied with the execution of the incorporation process. As of 2011, however, things took a significant turn for the worse as the number of acts that had not been incorporated, despite the deadline for their compliance date in the EU Member States had passed, increased significantly. ${ }^{25}$

There is no single simple reason that explains why incorporating EU acts into the EEA Agreement has been so slow in recent years. Rather, there are number of factors that contribute to the problem. Certain developments within the EU have rendered the incorporation process more complicated. In addition, certain issues relating to Iceland specifically have caused considerable delays. The next section will address the changes within the EU that have negatively affected the incorporation process.

${ }^{21}$ EFTA Bulletin, Handbook in EEA EFTA procedures for incorporating EU acts into the EEA Agreement. Belgium 2015, 22-26, <www.efta.int/publications/bulletins/handbook-eea-efta-procedures-3191> accessed 10 June 2018.

22 Sven Norberg, Karin Hökborg, Martin Johansson, Dan Eliasson and Lucien Dedichen, EEA Law, A commentary on the EEA Agreements (Fritzes 1993) 142.

${ }^{23}$ Margrét Einarsdóttir, 'Upptaka afleiddrar löggjafar í EES-samninginn og innleiðing í íslenskan rétt' (n 9) 558.

${ }^{24}$ See further discussion on this topic in the report; Utenfor og innenfor, Norges avtaler med EU. (Oslo 2012) 95, <https://www.regjeringen.no/contentassets/5d3982d042a2472eb1b20639cd8b2341/no/pdfs/nou20122012 $0002000 d d d p d f s . p d f>$ accessed 4 May 2017.

${ }^{25}$ Margrét Einarsdóttir, 'Upptaka afleiddrar löggjafar í EES-samninginn og innleiðing í íslenskan rétt' (n 9) 559. 


\subsection{CHANGES WITHIN THE EU}

\section{1 [a] Regulations - the most common form of EU legislation}

The first change relates to the adoption of regulation rather than directives. In recent years the institutions of the EU seem to prefer to adopt secondary law in the form of regulations rather than directives, representing a break with previous practice. Regulations have thus become the most common form of secondary legislation. ${ }^{26}$

Regulations are 'directly applicable' in the EU Member States. They require no implementation; rather, they become a part of the national legislation of the Member States as soon as they come into force, as provided for in Article 288 TFEU. ${ }^{27}$ Regulations usually enter into force 20 days after their publication in the Official Journal. ${ }^{28}$ On the other hand, EU Member States need to implement directives into their national legislation, cf. Article 288 TFEU and are accorded a reasonable period of grace to do so. Directives generally do not enter into force in EU Member States until after the end of this period.

Per Article 102 of the EEA Agreement, secondary laws enacted by EU institutions and which the EEA Joint Committee have found to fall within the scope of the EEA Agreement, should enter into force simultaneously in the EU States and in the EEA EFTA States. ${ }^{29}$

As already explained extensive preparation is carried out by the EEA EFTA States before the EEA Joint Committee can decide on the incorporation of EU acts into the EEA Agreement. Inevitably, this process takes some time. On the basis of the foregoing, it is clear that the time the EEA EFTA States have to prepare for the incorporation of EU acts into the EEA Agreement, before the legislation enters into force in the EU Member States, is shorter in the case of regulations than directives. This change has certainly played a part in the increased problems concerning the incorporation of secondary law that the EEA EFTA States now face. ${ }^{30}$

\section{$3.1[b]$ The scope of the EEA Agreement}

Another factor complicating the implementation process is that it has become more difficult in some cases, to decide whether legislation falls within the scope of the EEA Agreement. When EU institutions are processing legislation, the EU Commission must, early in the

\footnotetext{
${ }^{26}$ See Sven Norberg and Martin Johansson, 'History of the EEA Agreement and the first twenty years of its existence', in C. Baudenbacher (eds), The Handbook of EEA Law (Springer 2016) 36. This can be verified in the search engine of the EFTA Secretariat, EEA-lex, see <http://www.efta.int/eea-lex $>$ accessed 6 January 2018.

${ }^{27}$ M. Elvira Méndez-Pinedo (n 16) 62.

${ }^{28}$ Niels Fenger, Michael Sánchez Rydelski and Titus Van Stiphout, European Free Trade Association (EFTA) and European Economic Area (EEA) (Kluwer Law International 2012) 132.

${ }^{29}$ Norberg, Hökborg Johansson, Eliasson and Dedichen (n 22) 142.

${ }^{30}$ See Halvard Haukeland Fredriksen and Christian N.K. Franklin, 'Of pragmatism and principles: The EEA Agreement 20 years on’ (2015) Common Market Law Review 629, 659-660 and Margrét Einarsdóttir, 'Vaxandi vandkvæði við framkvæmd EES-samningsins - upptaka afleiddrar löggjafar' ['The increasing problems with the execution of the EEA Agreement - the incorporation of EU Secondary Law'] (2016) Tímarit lögfræðinga 503, 507-509.
} 
process assess whether an act falls under the scope of the EEA Agreement. ${ }^{31}$ In most cases, this is clear. ${ }^{32}$ In other cases, however, the matter involves complex issues, some of which have indisputably become more difficult to tackle in recent years. ${ }^{33}$

One reason for this is the fact that the EU's three-pillar system was abolished via the Lisbon Treaty. ${ }^{34}$ Since then, the division between the internal market legislation, falling within the scope of the EEA Agreement, and other legislation, falling outside its scope in most cases, became unclear, as this distinction was no longer relevant to the EU Member States. ${ }^{35}$ In addition, following the abolition of the three-pillar system, legislation adopted by EU institutions is at times more comprehensive than before, and covers various fields ${ }^{36}$ This means that a particular act can partly fall under the scope of the EEA Agreement, while other parts of the same act do not. ${ }^{37}$ Thus, it can be more difficult to reach an agreement in the EEA Joint Committee, concerning which legislation should be incorporated into the EEA Agreement. This causes delays in the incorporation process. ${ }^{38}$

An example of this is the 'citizen rights' Directive 2004/38. In the view of Iceland (and Liechtenstein) some part of the directive did not fall within the scope of the EEA Agreement. The EU however was determined from the very beginning that the directive should be wholly incorporated into the EEA Agreement. This opinion does not appear to have been supported by any legal arguments, rather resting on a political assessment of the importance of the Directive for the internal market. ${ }^{39}$ Directive 2004/38 was the subject of discussion in the EEA Joint Committee for three years. The EU finally lost patience and activated the measures contained in Article 102 of the EEA Agreement. This action

${ }^{31}$ Cf. Article 99 of the EEA Agreement. See Fenger, Rydelski and Van Stiphout (n 28) 129-130 and Knut Almestad, 'The Notion of 'Opting Out', in C. Baudenbacher (eds.), The Handbook of EE A Law (Springer 2016) 89.

32 The EEA Agreement and Norway's other agreement with the EU, Meld.St. 5 (2012-2013) 15

<https://www.regjeringen.no/globalassets/upload/ud/vedlegg/europa/nou/meldst5_ud_eng.pdf> accessed 10 January 2018.

${ }^{33}$ Iceland's Accession Negotiations (n 7) 115-116. See also The EEA Agreement and Norway's other agreement with the EU (n 32) 12.

${ }^{34}$ Jean-Claude Piris, The Lisbon Treaty, A legal and political analysis (Cambridge University Press 2010) 177.

35 Iceland's Accession Negotiations (n 7) 115 and European Economic Area, Joint Parliamentary Committee,

Report. The review of the EEA. (Brussels 3 May 2012) 3,

$<$ http://www.efta.int/sites/default/files/documents/advisory-bodies/parliamentary-committee/jpcreports/report2-2012-05-03.pdf> accessed 19 January 2018.

${ }^{36}$ Jóhanna Jónsdóttir, Europeanization and the European Economic Area, Iceland's participation in the EU's policy process (Routledge 2013) 52 and Fredriksen and Franklin (n 30) 654. See also The EEA Agreement and Norway's other agreement with the EU (n 32) 15-16 and EEA Joint Parliamentary Committee. Report on the future of the EEA and the EU's relationship with the small-sized countries and Switzerland. (Brussels 30 May 2013) 7, $<$ http://www.efta.int/sites/default/files/documents/advisory-bodies/parliamentary-committee/jpcreports/eea-jcp-report-eea-review.pdf $>$ accessed 19 January 2018.

37 The review of the EEA (n 35) 5.

38 This issue was brought up in the EEA Joint Parliamentary Committee Resolution on future perspectives for the European Economic Area, in 2008, wherein it was stated that: ' ... whereas a clear distinction between the Internal Market and other EU activities is crucial to the EEA EFTA States, it is becoming increasingly irrelevant in the EU, and as a result, a growing number of legal acts and policy initiatives that are relevant to the EEA also include elements that are not covered by the EEA Agreement; [...] which will make it increasingly difficult to define EE $A$ relevance, and consequently, to reach agreement on their incorporation into the EEA Agreement.'

39 As noted by a Commission official when interviewed about Directive 2004/38: 'Sometimes our stance is that things should be EEA relevant because we want them in. In these cases, we do not discuss the legal details. It is relevant because we say it is relevant [...].' See Jónsdóttir (n 36) 107. 
amounted to a threat from the EU to the effect that the part of the Annex that relates to the free movement of people would be provisionally suspended, if the Directive were not incorporated. The EEA EFTA States thus finally agreed to incorporate the acts in question into the EEA Agreement.

As illustrated by the incorporation process of Directive 2004/38, it appears that if the EU is determined that a particular act should be incorporated into the EEA Agreement, the EEA EFTA States are in a weak position to prevent it. ${ }^{40}$ Strictly speaking, the EEA EFTA States enjoy a veto right on the basis of Article 102 of the EEA Agreement, but as explained above, making use thereof may entail serious consequences. This veto right has therefore never been used. ${ }^{41}$

\section{1 [c] Increased constitutional problems in the incorporation process}

The third change that has occurred, is the increase in the number of EU agencies over the last few years. This change has led to increased constitutional problems in the incorporation of EU acts into the EEA Agreement, especially in Iceland. Many of the EU agencies have been granted powers to make decisions that are binding for individuals, legal entities and authorities in the EU Member States. ${ }^{42}$ Such transfer of power to international organisations raises question of compatibility with the Icelandic constitution.

The Icelandic Constitution does not have a provision that specifically permits the transfer of power to international organisations. ${ }^{43}$ After the signing of the EEA Agreement on 2 May 1992, an intense dispute arose as to whether the Agreement was compatible with the Icelandic Constitution. ${ }^{44}$ The Minister for Foreign Affairs appointed a committee of four respected lawyers ${ }^{45}$ to assess whether the Agreement on the European Economic Area entailed a greater transfer of powers to an international organisation than was compatible with the Icelandic Constitution. ${ }^{46}$ The conclusion of the committee was that the Constitution permits a transfer of power to international organisations, if it is delimited, well defined and

\footnotetext{
${ }^{40}$ There are other examples that demonstrate the difficult situation Iceland faces when it either doesn't want a particular legislation to become part of the EEA Agreement (for substantive reasons), or it consider the legislation to fall outside the scope of the Agremeent. The incorporation of Directive 89/662/EEC concerning veterinary checks in intra-Community trade with a view to the completion of the internal market, that allows the import of raw meat to Iceland is a good example. Iceland was against the incorporation of this Directive but they finally gave in. Iceland then implemented the Directive incorrectly, as was established by the EFTA-Court in Case E-17/15 Ferskar kjötvörur ehf v. the Icelandic State, [2016] Report of the EFTA Court 4. See also the Joined Cases E-2/17 and E-3/17 EFTA Surveillance Authority v. Iceland, [2017] Report of the EFTA Court 727.

${ }^{41}$ Margrét Einarsdóttir, 'Upptaka afleiddrar löggjafar í EES-samninginn - Hvað er unnt að gera betur?' ['The incorporation of EU secondary law into the EEA Agreement - What improvements can be made?'], (2016) Tímarit lögfræðinga 3, 34-37.

${ }^{42}$ Fredriksen and Franklin (n 30) 676. See also Morten Egeberg and Jarle Trondal, 'National Administrative Sovereignty. Under Pressure', in E. Eriksen and J. Fossum (eds.), The European Union's Non-Members. Independence under hegemony? (Routledge 2015) 173-174 and 178.

${ }^{43}$ Davíð Dór Björgvinsson, 'Stjórnarskrárákvæði um framsal valdheimilda ríkisins til alpjóðastofnana' ['The Icelandic Constitution and the Transfer of Powers to International Organisations'], (2003) Rannsóknir í félagsvísindum IV 213.

${ }^{44}$ Davíð Dór Björgvinsson, EES-réttur og landsréttur [EEA law and national law] (Codex 2006) 381.

${ }^{45}$ Dór Vilhjálmsson Supreme Court Attorney; Professor Gunnar G. Schram; Professor Stefán Már Stefánsson; and Ólafur W. Stefánsson, Office Manager.

${ }^{46}$ See the Report of the committee appointed by the Minister of Foreign Affairs on the Constitution and the EEA Agreement, 6 July 1992, Annex I to Legisl. Doc. 29, 116 th Legislative Session, 1992-93.
} 
not overly onerous for any Icelandic parties. The transfer of power that the EEA Agreement involved was considered to fall within these limits and was thus in accordance with the provisions of the Constitution. ${ }^{47}$ This conclusion, however, did not go uncontested. ${ }^{48}$

As was the case with the entry into force of the EEA Agreement itself, there have been several instances of complex constitutional issues as regards whether EU acts designated to be incorporated into the EEA Agreement were compatible with the provisions of the Icelandic Constitution. In such cases, the solution has been to appoint respected academics to provide their opinion as to whether the acts in question are compatible with the provisions of the Constitution. In an opinion by Professor Björgvinsson on transfer of power to international organisations regarding the implementation of regulation 1/2003 from 30 October $2004^{49}$, it is stated that 'to describe the legal situation in Iceland it can be said that in legal execution and academic writing an unwritten rule has been formed that allows the general legislature to delegate state power to a limited extent', meeting certain criteria. ${ }^{50}$

Over the years difficult and repeated constitutional problems have risen in the incorporation process and with increase in number of EU agencies (with power to take binding decision) such constitutional problems have become more frequent in Iceland. ${ }^{51}$ One may here refer to events surrounding the banking crisis, which caused significant constitutional problems in both Iceland and Norway. ${ }^{52}$

Following the collapse of the banking system in 2008, work was initiated by the EU to create a new, extensive regulatory framework for the supervision of financial markets. Three new supervisory bodies were established: the European Banking Authority ${ }^{53}$, the European Insurance and Occupational Pensions Authority ${ }^{54}$ and the European Securities and Markets Authority ${ }^{55}$. Those supervisory agencies set up were to be granted powers to adopt binding

\footnotetext{
${ }^{47}$ See the Report of the Committee appointed by the Minister of Foreign Affairs on the Constitution and the EEA Agreement (n 46) and Björg Thorarensen, 'Stjórnarskrárákvæði um framsal ríkisvalds, parfar eða óparfar breytingar á stjórnarskrá?' ['Transfer of power based on the Constitution, necessary or unnecessary changes on the Constitution?'], in S. Ólafsdóttir (eds.), Fullveldi i 99 ár, safn ritgerða til heiðurs dr. Davíð Fór Björgvinssyni sextugum (Hið íslenska bókmenntafélag 2017) 124.

${ }^{48}$ Einarsdóttir, 'Vaxandi vandkvæði við framkvæmd EES-samningsins - upptaka afleiddrar löggjafar' (n 30) 525.

${ }^{49}$ See Annex VII to Legisl. Doc 617, 131th legislative session, 2004-2005.

${ }^{50}$ Based on this unwritten rule the general legislature is allowed to delegate state power if the following criteria is met; The transfer is based on law and is delimited and well defined, it is based on an agreement that provides mutual rights and obligations, the international organisations to whom the power is assigned are founded on democratic principles, the transfer does not lead to the curtailment of constitutionally protected rights of citizens and the transfer can be cancelled. See Annex VII to Legisl. Doc 617, 131 th legislative session, 2004-2005, Björgvinsson, 'Stjórnarskrárákvæði um framsal valdheimilda ríkisins til alpjóðastofnana' (n 43) 220 and Björgvinsson, EES-réttur og landsréttur (n 44) 479. See also the Report of the Committee appointed by the Minister of Foreign Affairs on the Constitution and the EEA Agreement (n 46) and Einarsdóttir, 'Vaxandi vandkvæði við framkvæmd EES-samningsins - upptaka afleiddrar löggjafar' (n 30) 527-531. See also Davíð Dór Björgvinsson, 'EES- og framsal ríkisvalds' ['EEA and transfer of state power']. Afmalisrit Dór Vilhjálmsson sjötugur 9. júni 2000. (Orator 2000).

51 Einarsdóttir, 'Vaxandi vandkvæði við framkvæmd EES-samningsins - upptaka afleiddrar löggjafar' (n 30) 526.

52 There are other recent incidents of constitutional complications in Iceland, f.e. the pending incorporation of the 'European Union's Third Enegery Packages'. Regulation 713/2009 established an Agency for the Cooperation of Energy Regulators (ACER) and at the time of the writing it is unclear whether that act will be considered compatible with the Icelandic Constitution by Alpingi.

53 EBA.

54 EIOPA.

55 ESMA.
} 
decisions with respect to the EEA EFTA States' and the EU Member States' supervisory agencies and concerning financial undertakings. Iceland and Norway were of the opinion that there was a doubt as to whether the above regulations were compatible with their constitutions. For this reason, there were considerable delays in the incorporation process of the acts into the EEA Agreement.

Early in the incorporation process of the said regulations, the Icelandic state entrusted Professor Thorarensen and Professor Stefánsson, to give their opinions on whether the regulatory framework was compatible with the Icelandic Constitution. In their opinion, dated 25 April 2012, it is stated that the transfer of power to the above-mentioned agencies did not fit 'within the constitutional custom rule that the general legislative authority may transfer state power to a limited extent to international organisations' ${ }^{56}$

The above-mentioned regulations also created constitutional problems in Norway. The Norwegian Constitution contains a provision that permits the transfer of powers to international organisations by a three-fourths majority, but restricts this transfer to international organisations of which Norway is a member of, cf. Article 115 of the Norwegian Constitution. As Norway is not party to the three-abovementioned supervisory agencies, the incorporation of the aforementioned acts was not adjudged compatible with the Norwegian Constitution.

Iceland and Norway, therefore, had a joint interest in persuading the EU to agree to substantive adaptations to the said acts. This proved a difficult task, but finally, on the $14^{\text {th }}$ of October 2014, the EU and the EEA EFTA States signed a joint declaration to the effect that the assignation of power assumed in the regulations would be transferred to the EFTA Surveillance Authority (ESA) and not to the aforementioned supervisory agencies of the EU. ${ }^{57}$ According to the agreement, it is assumed, however, that the decisions of ESA will be based on a proposal or 'a draft', which the EU supervisory agency involved would prepare. ${ }^{58}$

It is interesting to compare the procedures in Norway and Iceland in the wake of the above agreement with the EU. Academics disagreed in Iceland on whether the adapted acts were compatible with the Icelandic Constitution. The district court judge Magnússon was asked to provide an opinion concerning whether these EU regulations on the supervision of financial markets, with the before mentioned substantive adaptations, respects the rules of the Icelandic Constitution with reference to the transfer of powers. It was his conclusion that this was the case. Professor Thorarensen, however disagreed. ${ }^{59}$ On 23 September 2016, Alpingi finally agreed to authorise the government of Iceland to ratify, on Iceland's behalf, the incorporation of a part of the aforementioned regulatory framework on the supervision of financial markets into the EEA Agreement. ${ }^{60}$

\footnotetext{
${ }^{56}$ See the Opinion of Björg Thorarensen and Stefán Már Stefánsson on the Constitutionality of the European System of Financial Supervision, (Reykjavík, 25 April 2012) Annex XXXI to Legisl. Doc. 1109, 145 th legislative session 2015-2016. Björg Thorarensen and Stefán Már Stefánsson came to the same conclusion in their Opinion on the Constitutionality of the EU regulation 1193/2011 establishing a system of the Union's emissions, (Reykjavík 12 June 2012).

${ }^{57}$ Conclusion adopted by the EU and EEA-EFTA Ministers of Finance and Economy, 14 October 2014. $<$ www.fjarmalaraduneyti.is/media/frettir2014/Sameiginleg-yfirlysing-fjarmalaradherra-EES-og-EFTArikjanna-(a-ensku).pd)> accessed 19 February 2018.

${ }^{58}$ The Opinion of Skúli Magnússon regarding the constitutionality of certain new EE $A$ acts regarding Financial Supervision, Annex XI to Legisl. Doc. 1109, 145 th legislative session 2015-2016.

59 Thorarensen (n 47) 139-141.

${ }^{60}$ See Legisl. Doc. 1109 - case 681, 145 th legislative session 2015-2016.
} 
In Norway, however, the legal situation was much clearer after the substantive adaptations were made to the before mentioned financial acts. On 13 August 2016, Stortinget (the Norwegian Parliament) granted the Norwegian government authorisation, on the basis of Article 115 of the Norwegian Constitution (which requires a three-fourths majority), to approve the incorporation of the aforementioned regulatory framework in the field of supervision of the financial markets into the EEA Agreement. ${ }^{61}$ Following the resolution of the constitutional constraints in both Iceland and in Norway, on 30 September 2016, the EEA Joint Committee approved the incorporation of a part of the regulatory framework into the EEA Agreement. ${ }^{62}$

This regulatory framework came into effect within the EU as early as 2010, six years before the first part of these regulations were incorporated in the EEA Agreement. In the meantime, 178 acts in the field of supervision of financial markets awaited incorporation into the EEA Agreement. In comparison, the backlog in past years has numbered between 418 and 550 acts. ${ }^{63}$ It is therefore clear that constitutional problems in the incorporation of acts into the EEA Agreement have accounted for a considerable part of the increased incorporation backlog in recent years.

\subsection{UNIQUE ICELANDIC CONDITIONS - RULES ON PARLIAMENTARY PROCEDURE}

Other factors then discussed above have also contributed to complications and delays in the incorporation process. This section will address the preparation process in Iceland.

Decisions concerning whether EU acts should be a part of the EEA agreement are, as previously stated, made during the meetings of the EEA Joint Committee. Before such proposals are submitted to the EEA Joint Committee, extensive preparations are carried out where the EFTA Secretariat, the sub-committees of the EFTA Standing Committee and working groups play key roles. ${ }^{64}$ Detailed rules of procedure, set out in the Handbook on EEA EFTA procedures, established by the EFTA Standing Committee, apply to the preparation of the decisions of the EEA Joint Committee. ${ }^{65}$

In addition, Icelandic rules apply that provide for the manner in which to prepare for the decision of the EEA Joint Committee in Iceland. These rules were approved by the Presidential Committee of Alpingi, first in 1994 and revised on 16 August 2010 and thereafter entitled 'rules on the parliamentary procedure for matters concerning EEA' ${ }^{66}$. Consultation with Alpingi in the incorporation process was strengthened by the new rules, and if an EU

\footnotetext{
${ }^{61}$ See information material on the website <http://svw.no/en/news/aktuelt/propositions-on-theparticipation-in-the-eu-financial-supervision---adopted-by-the-parliament $>$ accessed 20 February 2018.

62 See information material on the website <http://www.efta.int/EEA/news/First-package-acts-EuropeanFinancial-Supervisory-Authorities-incorporated-EEA-Agreement-499496> accessed 20 February 2018. ${ }^{63}$ In 2011, the backlog was 544 acts, in 2012, the backlog was 418 acts and in the year 2013, it was 506 acts, see the article by Einarsdóttir, 'Upptaka afleiddrar löggjafar í EES-samninginn og innleiðing í íslenskan rétt' (n 9) 559. In 2014, the backlog was 428 acts, see the annual report of the EEA Joint Committee from 14 October 2015.

${ }^{64}$ EFTA Bulletin, Handbook in EEA EFTA procedures for incorporating EU acts into the EEA Agreement (n 21) 2226.

65 The rules entered into effect on 20 October 2014 and were updated in October 2016, see

$<$ www.efta.int/publications/bulletins/handbook-eea-efta-procedures-3191> accessed 10 June 2018.

${ }^{66}$ Here after 'rules on the parliamentary procedure'. In Icelandic; 'reglur um pinglega meðferð EES-mála'.
} 
act needs to be implemented into Icelandic law through amendments to statutory laws ${ }^{67}$, it must be submitted for review three times to Alpingi before being finally incorporated into the EEA Agreement.

The first time an EU act must be submitted to the Foreign Affairs Committee of Alpingi is at the so-called 'standard sheet stage'. ${ }^{68}$ According to Article 2 of the 'rules on the parliamentary procedure', the consultations shall usually not take longer than two weeks. In practice, however, this usually takes a number of months, as the members of parliament have taken a considerable time to scrutinize the EU acts. ${ }^{69}$ It is interesting to compare this part of the procedure in Iceland with the procedure in Norway, as there is no such consultation with Stortinget at this stage (ie standard sheet stage) in the incorporation process in Norway. ${ }^{70}$ This part of the procedure in Iceland has caused delays in the incorporation process.

The second time an EU act must be submitted to the Foreign Affairs Committee of Alpingi is to consult the national parliament about the draft, for the decisions of the EEA Joint Committee, to incorporate the act into the Agreement. This consultation takes place a few days before the meeting of the Committee. The same applies in Norway, as consultation with the European Consultative Committee of Stortinget, also take place concerning the same 'draft', a few days before the meeting in the EEA Joint Committee. It appears however that the consultations in Norway differ in nature from those in Iceland. In Iceland, experts from the ministries meet with the Foreign Affairs Committee, while in Norway, it is the minister responsible for EEA issues as well as, as appropriate, 1-2 ministers who attend the meeting. According to an expert in the Norwegian Ministry of Foreign Affairs and data from the Ministry, technical issues are not discussed during these meetings. Instead, discussions are more political in nature, and address the political interests of Norway in the EEA collaboration and the challenges facing Europe. ${ }^{71}$ In Iceland, however, the experts of the ministries are often expected to respond to questions regarding the substance of the acts. Overall, this part of the process is smooth in both countries and does not cause undue delays. $^{72}$

The third reason for which an EU act must be submitted to Alpingi is for the purposes of requesting the parliament to lift constitutional requirements. This applies if an act is incorporated into the EEA Agreement with constitutional requirements, as provided for in Article 103 of the EEA Agreement. ${ }^{73}$ In practice, such requirements are made if the act in

\footnotetext{
${ }^{67}$ That is it will be implemented through amendments to statutory law, after it has been incorporated into the EEA Agreement, (by which time it will have transformed into an EEA act).

${ }^{68}$ Early in the incorporation process leading to incorporation of EU rules into the EEA Agreement, the EFTA Secretariat sends, what has been termed a standard sheet, to experts in the Icelandic ministries. The standard sheet requires the experts to specify possible general EEA horizontal challenges concerning the EEA, eg provisions containing references to acts not incorporated into the EEA Agreement, provisions raising possible two-pillar issues etc. See EFTA Bulletin, Handbook in EEA EFTA procedures for incorporating EU acts into the EEA Agreement (n 21) 23.

${ }^{69}$ Einarsdóttir, 'Upptaka afleiddrar löggjafar í EES-samninginn - Hvað er unnt að gera betur?' (n 41) 15.

70 ibid 38.

${ }^{71}$ Einarsdóttir, 'Upptaka afleiddrar löggjafar í EES-samninginn - Hvað er unnt að gera betur?’ (n 41) 17-18 and 39-40.

72 ibid 18.

${ }^{73}$ Article 103(1) of the EEA Agreement, states: 'If a decision of the EEA Joint Committee can be binding on a Contracting Party only after the fulfilment of constitutional requirements, the decision shall, if a date is contained therein, enter into force on that date, provided that the Contracting Party concerned has notified the other Contracting Parties by that date that the constitutional requirements have been fulfilled.'
} 
question will require amendments to statutory law during the implementation, cf. Article 21 of the Icelandic Constitution. A similar procedure takes place in Norway if constitutional requirements have been made, cf. Article 103 of the EEA Agreement. According to the provisions, the EEA EFTA States have six months to lift such reservations, although, as a rule, this process has taken longer. ${ }^{74}$

\section{THE MAIN REASONS FOR IMPLEMENTATION DIFFICULTIES}

Once an EU act has been incorporated into the EEA Agreement, the EEA EFTA States are under an obligation to implement the act in their national legislation, cf. Article 7 of the EEA Agreement. The precise starting date of the obligation is confirmed in the ruling of the EFTA Court in Case E-15/12 Jan Anfinn Wabl v. the Icelandic State, where is stated that the implementation must have taken place at the latest on the implementation date in the EU or when the Joint Committee Decision enters into force, whichever is later. Any later date constitutes an infringement of the EEA Agreement. ${ }^{75}$

Since the EEA Agreement entered into force, the implementation of directives into national legislation has represented a highly demanding task for the Icelandic executive and legislative branches. There have been periods in which this task has been completed successfully and Iceland has placed well in comparison with other EU and EEA EFTA States. However, there have also been times during which this task has not gone so well, and over the past few years, Iceland has performed poorly in the implementation of directives into national law and has not complied with its obligations on the basis of the EEA Agreement. $^{76}$

\subsection{IMPLEMENTATION PROBLEMS THAT THE EU AND ICELAND HAVE IN COMMON}

European scholars in the field of political science have conducted comprehensive researches on the causes of the implementation problems in the EU Member States. As the process for implementing directives into national law is the same in the EEA EFTA States as in the EU Member States, these reseraches provide an important insight concerning the root causes of implementation problems in Iceland.

European academics appear to agree on a number of factors they believe explain delayed or incorrect implementation of directives into the national legislation of the EU

\footnotetext{
74 During the period from 1 May 2008 to 10 September 2013, the Icelandic state was unable to lift constitutional reservations within six months in the majority of cases. Thus, during the period, an average of 429 days passed from the day that the act was approved with constitutional reservations in the EEA Joint Committee until Alpingi lifted the reservation. In comparison, the process took 402 days in the Stortinget. The Icelandic state exceeded the six-month deadline in $73 \%$ of cases, while the Norwegian state exceeded the deadline in $65 \%$ of cases. This information was obtained from the unpublished report of the EFTA Secretariat from 28 October 2013 which the author was kindly granted permission to use for research purposes. Via e-mails, dated 15 March 2017, the EFTA Secretariat confirmed that they did not have comparable information after 2013.

${ }^{75}$ E-15/12 Jan Anfinn Wablv. The Icelandic State, [2013] Report of the EFTA Court 534. The judgment only deals with implementation of directives, but the same must apply to regulations.

${ }^{76}$ Einarsdóttir, 'Upptaka afleiddrar löggjafar í EES-samninginn og innleiðing í íslenskan rétt' (n 9) 569-572.
} 
Member States. ${ }^{77}$ Thus, it is generally agreed that unclear directives, which are often open to divergent interpretations, lead to delays or incorrect transposition. ${ }^{78}$ In addition, it is a common issue in the academic literature on this subject that a lack of manpower and funds in the administration, explain difficulties in the implementation process. ${ }^{79}$ Moreover, interest groups appear to be able to exercise considerable influence on the implementation process, if they believe that the substance of the directive is contrary to their interest. ${ }^{80}$ Studies have also demonstrated that linking the implementation of a directive to various other changes that the local authorities wish to make, can lead to delays. ${ }^{81}$ All of these aspects have also had an impact in the implementation process in Iceland and caused delays, which will be analysed below.

First, one may mention that unclear directives cause as great, or even greater, difficulties in the implementation process in Iceland than is generally the case within the EU Member States. Falkner et al. argue that the 'problems of interpretation are all the more likely if those who have to [implement] a Directive are not directly involved in its negotiation' ${ }^{82}$ The EEA Agreement provides for limited possibilities for influencing the formulation of new acquis. ${ }^{83}$ Moreover, the Icelandic administration does not have the manpower to monitor all acts that are under development in the EU institutions. ${ }^{84}$ This can cause difficulties during the implementation stage..$^{85}$

\footnotetext{
77 See Gerda Falkner, Olivia Treib, Miriam Hartlapp and Simone Leiber, Complying with Europe EU Harmonisation and Soft Law in the Member States, (Cambridge University Press 2005), see specially 277-316. Robert Thomson, René Torenvlied og Javier Arregui, 'The Paradox of Compliance: Infringements and Delays in Transposing European Union Directives', 37 (2007) British Journal of Political Science 685. Ellen Mastenbroek, 'Surviving the deadline. The Transposition of EU Directives in the Netherlands', (2003) European Union Politics 371. Ernst M.H. Hirsch Ballin and Linda A.J, Co-actorship in the Development of European Law-making. The Quality of European Legislation and its Implementation and Application in the National Legal Order (T.M.C.Asser Press 2005). See also Margrét Einarsdóttir, 'Innleiðing afleiddrar löggjafar í íslenskan rétt - ástæður vandans og hvað er unnt að gera betur?' ['The implementation of secondary law into Icelandic national law - The cause of the problem and what improvements can be made?'] (2018) Tímarit lögfræðinga 3, 29-31.

${ }_{78}$ Falkner, Treib, Hartlapp and Leiber (n 77) 286-287, Gerda Falkner, Miriam Hartlapp, Simone Leiber and Oliver Treib, 'Non-Compliance with EU Directives in the Member States: Opposition through the Backdoor?' <https://www.ihs.ac.at/publications/pol/2004WestEuropeanPolitics.pdf> accessed 12 March 2018 (a slightly revised version of the paper is published in West European Politics 27(3) (2004) 452-473) and Mastenbroek, (n 77) 375.

${ }_{79}$ Oliver Treib, 'Implementing and complying with EU governance outputs', (2008) Living Reviews in European Governance 2. See also, Falkner, Hartlapp, Leiber and Treib (n 78). The paper states on p. 10: 'Several cases show that even if the necessary adaptations are not of major magnitude and importane [...] and even if the government as such is not unwilling to transpose, there may still be a delay or (less frequently) an incorrect transposition. In quite many cases this can be attributed to administrative shortcomings. The country where this pattern most clearly occurs is Luxembourg. [...] The main reason for the frequent occurrence of this factor is administrative overload due to a lack of resources in the small country. Equipped with a comparatively low number of staff, the administration is constantly at its limits, having to deal with the national as well as the increasing number of European matters.'

${ }_{80}$ Falkner, Treib, Hartlapp and Leiber (n 77) 303-309.

81 ibid 313-316. See also Falkner, Hartlapp, Leiber and Treib (n 78) 11-13.

${ }_{82}$ Falkner, Hartlapp, Leiber and Treib (n 78) 14.

${ }_{83}$ Cf. Article 99 and Article 100 of the EEA Agreement.

${ }_{84}$ Report of a Steering Committee on the execution of the EEA Agreement, Prime Minister's Office. (December 2015) 24 <https://www.stjornarradid.is/media/forsaetisraduneyti-media/media/Skyrslur/skyrsla-styrihops-umframkvaemd-EES.pdf> accessed 10 June 2018.

85 This is supported by Report of a Steering Committee on the execution of the EEA Agreement (n 84), which states that: 'at present, the plan is to implement 80 acts in the field of financial markets and that up to 300 acts are
} 
Second, insufficient manpower and funds in the Icelandic administration have created significant difficulties in the implementation process. In the article by Falkner et al. ${ }^{86}$ it is stated that overloaded administrative sectors are a particularly difficult problem in smaller member states. This seems to be the case in Iceland. In addition, little has been done in Iceland to bolster education and improve the knowledge of the experts within the ministries about the complex tasks involved in the implementation of the EEA Agreement. ${ }^{87}$ Data, to which the Ministry for Foreign Affairs granted the author access for research purposes, also seem to support this, as the date reveals that delays in the implementation of the majority of acts stems, entirely from delays in the administrative branch itself and are not due to delays in Alpingi. ${ }^{88}$

Third, individual stakeholder groups in Iceland appear to exercise some influence on the implementation process. This is supported by the study carried out by Dr. Jónsdóttir in which she examined the impact of stakeholder groups in Iceland on the implementation process. The study shows that several stakeholder groups closely monitor legislation under development within EU institutions. ${ }^{89}$ Pressure from stakeholders, however, appears to only cause delays in the implementation process in isolated cases in Iceland and is not a major problem in the implementation process. ${ }^{90}$

Fourth, efforts to link implementation legislation to other legislative reform, which is not related to the EEA Agreement, has also caused delays in Iceland. ${ }^{91}$ The processing of a bill generally takes much less time, if it only contains provisions that must be implemented into the national legislation on the basis of the EEA Agreement, than if the same bill also deals with purely domestic legislative issues on which there may be different political views. ${ }^{92}$ For this reason, the Report of a Steering Committee on the execution of the EEA Agreement recommends that in order to facilitate the implementation of directives into the internal legal order, the implementation legislation should generally contain 'only provisions derived directly from the EEA obligation in question'. ${ }^{93}$

expected in the next few year. Employees have not been able to monitor the processing of the acts or to gain knowledge of their substance overseas from among the member states or in Brussels. This means that it is difficult to understand and analyse the material thoroughly.'

${ }^{86}$ Falkner, Hartlapp, Leiber and Treib (n 78) West European Politics (2004) 452-473.

${ }^{87}$ Jónsdóttir (n 36) 58-60. See also the Report of a Steering Committee on the execution of the EEA Agreement (n 84)

28-29, where is stated that: 'The Icelandic administrative branch is small, and there is, as a rule, a heavy workload on staff in ministries. In addition, the EEA issues have not generally been at the forefront in the prioritisation of tasks.'

${ }^{88}$ 'The Ministry for Foreign Affairs sent the author the data in question by e-mails on 6 January and 12 January 2017. The data revealed that during the period between 17 November 2014 and 31 May 2016, there were on average 8.7 directives that should have already been implemented by means of statutory laws, but were not. During the same period, there were 10.2 unimplemented directives that should have been implemented by means of administrative regulations. No comparable data for earlier periods is available. It should be noted however, that a much greater number of directives are implemented by means of administrative regulations compared to statutory law. Implementation of individual acts by means of administrative regulations is thus much quicker. See Einarsdóttir, 'Innleiðing afleiddrar löggjafar í íslenskan rétt - ástæður vandans og hvað er unnt að gera betur?’

(n 77 ) 49-52.

${ }^{89}$ Jónsdóttir (n 36) 62-63.

${ }^{90}$ Einarsdóttir, 'Innleiðing afleiddrar löggjafar í íslenskan rétt - ástæður vandans og hvað er unnt að gera betur?' (n 77) 40-42.

91 ibid.

92 Report of a Steering Committee on the execution of the EEA Agreement (n 84) 37.

93 ibid. 
Finally, the conclusions of academic literature referred to above diverge regarding the effect of the so called 'misfit hypothesis'. At its core, this hypothesis posits that if EU legislation is very dissimilar to domestic legislation, then its implementation will be more arduous and time consuming. If, however, the legislation is comparable to existing domestic legislation, the implementation will go smoothly. This hypothesis was not supported by the study of Falkner et al., although other academics have considered it to have more significance. ${ }^{94}$

Nevertheless, there appears to be more agreement that the 'misfit bypothesis' has more significance if the EU legislation involves changes to entrenched national models, eg legislation involving paternity leave in countries where only mothers have had such rights. Changes of this nature appear to meet greater resistance in the Member States. The most important aspect here, however, is which political parties are in power when such changes are to be implemented into the national legislation of the Member States. These changes can be strongly favoured by the government in power; in such cases, legislation is likely to be implemented quickly and smoothly. In other cases, however, such reforms may meet strong resistance, which can cause difficulties in the implementation process. ${ }^{95}$

It may be assumed that the same applies in Iceland. An example of this is the implementation of EU food legislation in Iceland. The legislation met strong political resistance by a conservative government in Iceland that was determined to protect domestic agriculture, and this led to delays in the implementation. Finally, the EFTA Court found that EU food legislation was inadequately implemented into Icelandic law. ${ }^{96}$ If, however, during this period, a more liberal political party had been in power, the legislation in question would undoubtedly have been favoured by the government and probably implemented in a satisfactory manner. ${ }^{97}$ As in the EU Member States, this hypothesis, however, only applies in a limited number of cases and does not explain the implementation difficulties in the majority of cases.

\subsection{IMPLEMENTATION PROBLEMS RESULTING FROM THE NATURE OF THE EEA AGREEMENT OR UNIQUE ICELANDIC CONDITIONS}

Although many of the difficulties in implementing directives into national law are similar in the EU Member States and the EEA EFTA States, other issues are unique to the latter. Moreover, there may be conditions unique to Iceland that can explain a part of the problem. These include various dissimilar aspects that require further discussion.

\section{2 [a] Implementation of Regulations}

Regulations are 'directly applicable' and require no implementation in the EU Member States. Instead, they become a part of the national legislation of the Member States as soon

\footnotetext{
${ }^{94}$ Falkner, Treib, Hartlapp and Leiber (n 77) 289-291.

95 ibid 291-294 and 309-313.

96 This was confirmed by the EFTA Court in E-17/15 Ferskar kjötvörur ehf. and the Icelandic State, [2016] Report of the EFTA Court 4 and Joined Cases E-2/17 and E-3/17 EFTA Surveillance Authority v. Iceland, [2017] Report of the EFTA Court 727.

${ }^{97}$ See further discussion in Jónsdóttir (n 36) 140-145.
} 
as they enter into force, cf. Article 288 TFEU. ${ }^{98}$ Regulations, however, need to be implemented into national law in Iceland and Norway, cf. Article 7 of the EEA Agreement.

It follows from the above that the authorities in Iceland and Norway must implement more acts (ie EEA relevant acts), into their legal order than the EU Member States and Liechtenstein. ${ }^{99}$ The execution of the EEA Agreement is therefore more time consuming for these countries, with the additional burden being placed on the Icelandic and Norwegian legislator and administration. This imbalance in workload between the EU and the EEA EFTA States, has increased in recent years. The reason is the EU used to prefer to enact secondary law in the form of directives but this modus operandi has recently changed, and, at present, regulations are the most common form of secondary legislation. ${ }^{100}$

It should, however, be noted that it is generally more complicated and time consuming to implement directives than regulations. ${ }^{101}$ In that sense, the implementation work itself should be more manageable than was previously the case.

\section{2[b] Less time for Implementation}

The EEA EFTA States have a shorter time in which to implement EEA acts into their legal order than the EU Member States, in most cases just one day, once an EU act has been incorporated into the EEA Agreement. If the deadline for implementation has already passed in the EU Member States, on the incorporation of the relevant directive into the EEA Agreement, the EEA EFTA States are under an obligation to implement the directive into their internal legal order from the date of entry into force of the decision of the EEA Joint Committee. ${ }^{102}$ The same applies to regulations. ${ }^{103}$

The fact is that most Icelandic ministries do not begin preparations for implementation until after an act has been incorporated into the EEA Agreement. ${ }^{104}$ On some occasions, it is uncertain whether an act will be incorporated unchanged into the Agreement or whether substantive adaptations will be made, thus making it difficult to begin preparations for implementation. In most cases, however, it is clear early in the incorporation process that no substantive adaptation will be needed. ${ }^{105}$ It goes without saying that it is impossible to implement an EEA act into the Icelandic legal order in a single day, regardless of whether it is to be implemented by statutory law or administrative regulation. It is essential therefore, that the Icelandic administration should begin preparations for implementation during the

\footnotetext{
98 Méndez-Pinedo (n 16) 62.

${ }^{99}$ Regulations are 'directly applicable' in the EEA EFTA State, Liechstenstein, because it is a monist state. See the Internal Market Scoreboard EFTA States, February 2007, p. 10, <http:/ /www.eftasurv.int/press-publications/scoreboards/internal-market-scoreboards> accessed 15 May 2018.

100 See Norberg and Johansson (n 26) 36. This can also be verified in the search engine of the EFTA Secretariat EEA-lex (n 26). See also the article written by Egeberg and Trondal (n 42) 173-174.

101 Einarsdóttir, 'Innleiðing afleiddrar löggjafar í íslenskan rétt - ástæður vandans og hvað er unnt að gera betur?' (n 77) 47-49.

102 This is confirmed in case E-15/12 Jan Anfinn Wablv. the Icelandic State, [2013] Report of the EFTA Court 534.

${ }^{103}$ Einarsdóttir, ‘Upptaka afleiddrar löggjafar í EES-samninginn og innleiðing í íslenskan rétt’ (n 9) 567.

104 Einarsdóttir, 'Innleiðing afleiddrar löggjafar í íslenskan rétt - ástæður vandans og hvað er unnt að gera betur?’ (n 77) 49-50.

${ }^{105}$ Einarsdóttir, ‘Upptaka afleiddrar löggjafar í EES-samninginn - Hvað er unnt að gera betur?’ (n 41) 26-30, discusses special adaptations.
} 
incorporation process, as is already the practice in Norway. ${ }^{106}$ This does however not apply in the same way when an EEA Act has been incorporated into the Agreement with constitutional requirements, cf. Article 103, as the Icelandic administration often begins its preparations for the implementation bill in such cases prior to the resolution of the constitutional requirement, cf. Article 5 of 'rules on the parliamentary procedure'.

\section{2[c] Prolonged Legislative Processes - Democratic Deficit}

Alpingi's deliberations concerning implementation bills (ie EEA-related bills) tend to take a long time. ${ }^{107}$ Alpingi's administration collects data on the length of the EEA implementation process from the time a bill is submitted until it is approved as an act of law. ${ }^{108}$ According to this data, 435 implementation bills have been submitted to Alpingi between the $117^{\text {th }}$ legislative session in 1993-1994 and the $145^{\text {th }}$ legislative session in 2015-2016. During the period between the $117^{\text {th }}$ and $134^{\text {th }}$ legislative sessions, the average time these bills were considered was 67 days. However, during the period from the $140^{\text {th }}$ to the $145^{\text {th }}$ legislative sessions, the average was 111 days. These numbers show that the processing time before Alpingi has been getting significantly longer in recent years. It is important to note that these average figures do not include the EEA-related bills that were set aside. Such bills must be submitted again before the next legislative session, resulting in significant delays. In the period from the $140^{\text {th }}$ to the $145^{\text {th }}$ sessions, $41 \%$ of EEA-related bills were set aside..$^{109}$

\section{2[d] Translation of EE $A$ acts}

The EU employs a large number of translators responsible for translating European legislation into the 24 official languages of the EU Member States. However, Iceland and Norway do not enjoy such services. ${ }^{110}$ In Iceland, the Ministry for Foreign Affairs Translation Centre, is responsible for translating acts that fall within the scope of the EEA Agreement. ${ }^{111}$

For a long time, late translations caused considerable delays in the implementation process. This has, however, been remedied, and translations generally do not represent an obstruction in the implementation process. Every now and again, however, there are cases when the translation process of the act in question is very slow. Such acts may be dozens or

\footnotetext{
${ }^{106}$ Einarsdóttir, 'Innleiðing afleiddrar löggjafar í íslenskan rétt - ástæður vandans og hvað er unnt að gera betur?’ (n 77) 49-50.

107 ibid.

108 The data was sent to the author from the Offices of Alpingi on 16 January 2017.

109 Between the $117^{\text {th }}$ and the $145^{\text {th }}$ legislative sessions, almost $27 \%$ of these bills were set aside. For comparison in the period from the $117^{\text {th }}$ to the $134^{\text {th }}$ legislative sessions, only $15 \%$ were subject to the same fate, and in the period from the $140^{\text {th }}$ to the $145^{\text {th }}$ sessions, $41 \%$. It is therefore clear that the number of these bills that have been set aside has greatly increased in recent years.

${ }^{110}$ Information material on the website <https://www.ucl.ac.uk/european-institute/analysispublications/careers/kayes-translator-careers> accessed 10 April 2018. See also William Robinson, 'Translating Legislation: The European Union Experience', 2 (2014) The Theory and Practice of Legislation 185 and Fredriksen and Franklin (n 30) 664.

111 Report of a Steering Committee on the execution of the EEA Agreement (n 84) 21.
} 
hundreds of pages in length and/or extremely complicated and technical. The translation of such acts can cause delays in the implementation process. ${ }^{112}$

In exceptional cases, it may be necessary to exercise the authorisation contained in the second paragraph of Article 4 of the Official and Legal Gazette Act No. 15/2005, which authorises: "the publication of only the foreign text of an international treaty if the treaty relates to a specific group of people who, due to their education or other expertise, may be reasonably expected to understand the foreign language'.

In conclusion; there are many factors that contribute to the problems Iceland faces with the execution of the EEA Agreement. Some are due to changes in the EU, other due to the nature of the EEA Agreement or unique Icelandic conditions. Furthermore, some challenges that Iceland faces in the implementation process are similar to challenges in other EU Member States. The next section will address what can be done to improve the execution of the EEA Agreement in Iceland?

\section{HOW TO IMPROVE THE EXECUTION OF THE EEA AGREEMENT IN ICELAND?}

It is clear that the execution of the EEA Agreement in Iceland does not comply with Iceland's obligation under the EEA Agreement.

There are two principal reasons for this poor performance on the part of the Icelandic state. The first is a certain lack of willingness among Icelandic Members of Parliament to accept the realities of the EEA agreement, especially the lack of democratic control it inflicts. Secondly, developments within the EU have added new challenges to the execution of the EEA Agreement.

\subsection{FACING THE EEA AGREEMENT AS IT IS - INCORPORATION}

It is true that, from a legal standpoint, both the EU and the EEA EFTA States have veto powers with respect to the incorporation of EU acts into the EEA Agreement. At the time of the EEA Agreement's ratification, these veto powers were believed to be important for the purposes of preserving the sovereignty of the EEA EFTA States. ${ }^{113}$ In reality, however, this has not transpired to be an active veto power, as the use of it can result in the provisional suspension of legislation in the relevant Annex, cf. fifth paragraph of Article 102 of the EEA Agreement. However, perhaps because of this right of the EEA EFTA States, the EU has often shown great patience and willingness to reach an agreement and sometimes agreed on substantive adaptations to acts, on a request by Iceland, Norway or Liechtenstein. There have however also been instances in when the EU has lost its patience and threatened to invoke

\footnotetext{
112 Einarsdóttir, 'Innleiðing afleiddrar löggjafar í íslenskan rétt - ástæður vandans og hvað er unnt að gera betur?' (n 77) 56-58.

113 Norberg, Hökborg, Johansson, Eliasson and Dedichen (n 22) 143. Report of the European Committee about the relationship between Iceland and the EU. Prime Minister's Office 2007, 33

$<$ https://www.stjornarradid.is/media/forsaetisraduneyti-media/media/frettir/SkyrslaEvropunefndar-.pdf > accessed 12 April 2018 and Jóhanna Jónsdóttir, 'Can the EFTA states say 'no'? Article 102 and the incorporation of the Citizenship Directive into the EEA Agreement', (2009) Rannsóknir í félagsvísindum X $307,316$.
} 
the fifth paragraph of Article 102, to temporarily suspend a part of the Annex. ${ }^{114}$ Moreover, it has generally been quite difficult, for the EEA EFTA States to achieve substantive adaptations to acts. ${ }^{115}$

Despite this, the Icelandic state has a complicated and extensive consultation process with Alpingi during the incorporation process, which seems to assume that Icelandic Members of Parliament may realistically submit proposals for substantive adaptations to acts, or prevent an act from being incorporated into the EEA Agreement. In other words, this process does not accept the realities of the EEA Agreement, especially not the democratic deficit it entails.

This consultation causes significant delays in the incorporation process and, in fact, achieves little, as there is meagre material input from Members of Parliament. ${ }^{116}$ Even if substantive proposals were made during this consultation process, it is clear that there is little likelihood that such proposals would result in substantive adaptations to acts that are to be incorporated into the EEA Agreement. It is even less likely that a proposal from Member of Parliament to prevent an act from being incorporated into the EEA Agreement would actually have such an effect.

It is clear that changes are needed. From a democratic viewpoint, this does not mean that consultation with Alpingi in the incorporation process should be discontinued altogether. Where important Icelandic interests are at stake, Iceland should continue to employ any opportunities available to attempt to influence the EU legislation itself or to convince the EU to agree to substantive adaptations for Iceland. Here, the key is to convey the views of Iceland early in the EU's legislative process, that is while legislation is still being processed by the EU institutions. ${ }^{117}$ If Members of Parliament would have any comments on the legislation at this point, the Foreign Service could make an effort to try to influence the legislation accordingly.

Such a change would have two advantages; it would appear to be more likely that the EU would take into account the views of the EEA EFTA States if they were presented at this stage, rather than after the legislation has been approved by the EU institutions. Second, consultation with Alpingi at this stage would not delay the incorporation process. ${ }^{118}$

\subsection{FACING THE EEA AGREEMENT AS IT IS - IMPLEMENTATION}

Similar views as those presented previously apply to the powers of Alpingi to reject the implementation of EEA acts that have been incorporated into the EEA Agreements. It is true that neither regulations nor directives can have direct legal effect in the domestic legal order, unless they are made part of domestic law, either by the parliament or, if sufficient, by

\footnotetext{
114 Georges Baur, 'Suspension of Parts of the EEA Agreement: Disputes About Incorporation, Consequences of Failure to Reach Agreement and Safeguard Measures', in Carl Baudenbacger (eds.), The Handbook of EE A Law (Springer 2016) 73.

115 Einarsdóttir, ‘Upptaka afleiddrar löggjafar í EES-samninginn - Hvað er unnt að gera betur?’ (n 41) 26-30.

116 ibid 43.

117 At this point it could be easier for the Commission and the other 28 States to discuss Icelandic concerns and reach a compromise and solution to help an EEA partner state, before formally inviting Parliament and Council to discuss legislative proposal.

118 Einarsdóttir, 'Upptaka afleiddrar löggjafar í EES-samninginn - Hvað er unnt að gera betur?’ (n 41) 44.
} 
administrative regulation. ${ }^{119}$ However, the failure of the Icelandic authorities to implement EEA acts correctly into the Icelandic legal order might result in a response from the ESA and finally in the initiation of a case before the EFTA Court, for breaches of EEA law under the EEA Agreement, cf. Article 31 of the SCA. In addition, such a failure may entail state liability, per the Sveinbjörnsdóttir judgment. ${ }^{120}$

As data from Alpingi confirms, the processing of legislative implementation bills often takes a long time. The reason for this is that some Members of Parliament do not appear to accept having to pass laws that are created by EU institutions automatically. Rather, they wish to carry out substantive procedure on the legislation, even if delays in the implementation may entail the consequences described in the previous paragraph. Furthermore, the political priorities of the ruling government may have an effect on the implementation of legislation. ${ }^{121}$

In the opinion of this author, this long processing period reflects the resistance of Icelandic Members of Parliament to the democratic deficit or the lack of democratic control of the EEA Agreement. From a democratic point of view, this is understandable. Nevertheless, it is important that representatives in Alpingi take the obligations imposed on Iceland on the basis of Article 7 of the EEA Agreement seriously, and that they are well aware of the consequences of failing to do so. Both rights and obligations are part of the compromise of the EEA Agreement. As it is commonly said, 'you cannot both have your cake and eat it'.

Increasing consultation by the Icelandic administration with Alpingi while proposed legislation is still being considered by EU institutions might give the Members of Parliament an opportunity to have some impact on the legislation. This might lead to more trust and thus more efficient implementation of EEA acts into Icelandic law. As explained above, increased consultation at this stage could for the same reason, have a beneficial effect on the incorporation of EU acts into the EEA Agreement.

One must make the reservation, however, that the possibilities for the Icelandic government to have an impact on legislation under consideration in EU institutions remain limited. On the basis of Articles 99 and 100 of the EEA Agreement, the experts of the EEA EFTA States have certain participatory rights, but no voting rights, in the committees of the European Commission where the legislation is being prepared. The EEA EFTA States are also not represented in the European Parliament. ${ }^{122}$ Through the Lisbon Treaty, the powers

119 This was clearly confirmed for the first time in the ruling of the EFTA Court in the Case E-4/01 Karl K. Karlsson v. the Icelandic State, [2002] Report of the EFTA Court 240 (para. 28). See further discussion in section 2.2.

120 The Supreme Court of Iceland, judgment from 16 December 1999, Case No. 236/1999 the Icelandic State v. Erla María Sveinbjörnsdóttir and counter suit, see also the judgment of the EFTA Court in the Case E-9/97 Erla Maria Sveinbjörnsdóttir v. the Icelandic State. [1998] Report of the EFTA Court 95. See further discussion on the liability of the Icelandic state due to violations of the EEA Agreement in the article by Margrét Einarsdóttir, 'Bótaábyrgð vegna brota á EES-rétti sem rekja má til æðstu dómstóla' ['State liability for breaches of EEAlaw committed by courts adjudicating at last instance’ (2011) Tímarit lögfræðinga 5 and Stefán Már Stefánsson, 'State Liability in Community Law and EEA Law', in C. Baudenbacher, P. Tresselt and T Örlygsson (eds.), The EFTA Court: Ten Years On (Hart Publishing 2005).

${ }^{121}$ Einarsdóttir, 'Innleiðing afleiddrar löggjafar í íslenskan rétt - ástæður vandans og hvað er unnt að gera betur?’ (n 77) 54.

122 See more detailed discussion in the article of Erik O. Eriksen, 'Democracy Lost: The EEA Agreement and Norway's Democratic Deficit'. ARENA working paper (online), Centre for European Studies, (21 October 2008) 
of the European Parliament in the legislative process were considerably strengthened. ${ }^{123}$ This change further reduced the possibility for Icelandic authorities to exert influence on the development of secondary law. ${ }^{124}$ Moreover, the Icelandic state has no formal involvement in the Council where the legislation is finally approved by the Member States of the EU. ${ }^{125}$

In light of this, increased consultation with Alpingi at this stage will never represent a 'magic solution'. There is every likelihood that at least some Members of Parliament will continue to see their role as being to safeguard national interests when legislation originating in Brussels and on which Iceland has had little or no impact, is to be implemented into domestic law. This lack of democratic control is therefore likely to continue to cause delays in the implementation process.

\subsection{NEW CHALLENGES TO THE EXECUTION OF THE EEA AGREEMENT}

Certain developments within the EU have rendered the execution of the EEA Agreement more complicated and increased pressure on the administrative branch.

The increase in the number of EU agencies over the last few years, explain the increased constitutional problems in the execution of the EEA agreement, especially in Iceland. In order to facilitate the fulfilment of the obligations of the EEA Agreement Alpingi needs to incorporate provisions into the Icelandic Constitution, explicitly allowing transfer of power to international organisations. ${ }^{126}$ A Constitutional provision that permits transfer of power to international organisations will not solve every problem that might arise in the execution of the EEA Agreement. However, as the comparison of the Icelandic and Norwegian procedures in this article demonstrates, there is much more predictability in the case of a clear constitutional provision as is the case in the Norwegian Constitution, than when the assessment as to whether a transfer of power is compatible with the Constitution is based on an unwritten criteria formulated by academics.

Furthermore, other developments within the EU have called for increasingly complicated work on the part of the administrative branch, which are often time-consuming: Firstly, it has become more difficult to assess whether a given act falls within the scope of the EEA Agreement. Secondly, greater number of regulations, increasingly employed instead of directives, also means that there is additional pressure on the Icelandic administrative branch, when compared to the EU Member States. To respond to this new challenges, the

7-10. <http://www.sv.uio.no/arena/english/research/publications/arena-working-papers/2001-

2010/2008/wp08_21.pdf> accessed 10 February 2018.

${ }^{123}$ See f.e. Nigel Foster, Foster on EU Law (Oxford University Press 2013) 56.

124 Report on the future of the EEA and the EU's relations with the small-sized countries and Switzerland (n 36) 8. See also Report of a Steering Committee on the execution of the EEA Agreement (n 84) 12-13. Norway responded to the increased powers of the European Parliament by establishing an office in the premises of the European Parliament in Brussels in an attempt to have an impact, see again Report on the future of the EE $A$ and the EU's relations with the small-sized countries and Switzerland (n 36) 9 and Report of a Steering Committee on the execution of the EEA Agreement (n 84) 34.

125 See more detailed discussion in the article of Eriksen (n 122).

${ }^{126}$ See Ragnhildur Helgadóttir and Margrét Einarsdóttir, 'Iceland and the EEA'. In F. Arnesen, H.

Fredriksen, H. Graver, C. Vedder and O. Mestad (eds), Agreement on the European Economic Area. A Commentary (Hart Publishing 2018) and Thorarensen (n 47) 140-141. See also the work of the Constitutional Committee - phase I, (June 2014), which contains a discussion on the 'Transfer of power authorisations for the benefit of international co-operation', 11-16. See <https://www.forsaetisraduneyti.is/media/stjornarskra/starfstjornarskrarnefndar-1-afangaskyrsla.pdf $>$ accessed 18 June 2018. 
number of employees handling EEA issues within the ministries needs to be increased. At the same time, it is important to improve the knowledge of ministry employees as regards EEA matters and to provide them with training and education in this field.

\section{CONCLUDING REMARKS}

The EEA Agreement is the most extensive international agreement Iceland has entered into, and is vital to Iceland's economy. Despite this, the execution of the EEA Agreement by Icelandic authorities is not adequate in all respects. Iceland needs to improve its performance so that the execution of the EEA Agreement complies with its obligations. To achieve this goal it is necessary firstly, that Icelandic politicians stand ready to politically accept the EEA Agreement as it is in reality. Only by doing so will they be able to make the necessary changes so that the incorporation and implementation procedures will be generally smooth and without unnecessary delays. Secondly, Alpingi needs to incorporate provisions into the Icelandic Constitution, explicitly allowing a transfer of power to international organisations. Thirdly, as changes within the EU have added new challenges to the execution of the Agreement with increased pressure on the administrative branch, Icelandic administration needs to be strengthened with increased manpower and lifelong learning in the field of EEA law. 